Saputro Ahmad, B. G. and Utami, W. (2019). "A study of Ramadan effect on the Indonesia Stock Exchange", Management and entrepreneurship: trends of development, 4 (10), pp. 67-78. Available at: https://doi.org/10.26661/2522-1566/2019-4/10-06

ENTREPRENEURSHIP, TRADE AND EXCHANGE ACTIVITIES

Received:

28 November, 2019

1st Revision:

28 December, 2019

Accepted:

30 December, 2019
UDC: 336.7

DOI https://doi.org/10.26661/2522-1566/2019-4/10-06

\title{
A STUDY OF RAMADAN EFFECT ON THE INDONESIA STOCK EXCHANGE
}

\author{
Bimo Galuh Saputro Ahmad \\ Universitas Mercu Buana, Jakarta, Indonesia \\ ORCID: 0000-0002-8006-4551
}

\author{
Wiwik Utami \\ Universitas Mercu Buana, Jakarta, Indonesia \\ ORCID: 0000-0002-2313-3346
}

*Corresponding author email: bimogaluhsaputro@gmail.com

Abstract. This study aims to test whether there are significant anomalies in stock returns in Shaaban (before Ramadan), Ramadan, and Shawwal (after Ramadan) in the Indonesia Stock Exchange (IDX). Sample was selected based on the listed companies included in the Liquid 45 indices (LQ45). Data collection is based on weekly closing price in the period 2012 till 2017. Research design followed the event studies and assumes that capital market was semi strong. The analytical method is the Wilcoxon-test and Paired Sample T-test statistical models with a confidence level of $95 \%$ or $\alpha=0.05$. The results showed that there was no significant statistical difference between LQ45 returns and abnormal returns in Shaaban, Ramadan, and Shawwal in the research period. It revealed that there was not any anomalies effect of Ramadan in Indonesia Stock Exchange.

Keywords: event studies, Ramadan, returns, anomalies, Liquid 45, Indonesia Stock Exchange.

JEL Classification: H54, R53.

\section{INTRODUCTION}

The efficient market hypothesis (EMH) starts with the work of Eugene Francis Fama in 1970 who argued that the price of a financial asset had revealed all the information that exists in the value of the asset (Fama, 1970). According to his hypothesis, prices will move automatically following new information obtained by investors or capital market players, on other hand, an investor cannot predict the price movements. However, empirical studies have concluded that there are certain days, months, or certain other periods that appear to conflict with the efficient market hypothesis. Empirical facts that reveal the presence of symptoms or seasonal calendar influencing the movement of prices of financial assets called efficient market anomalies (Bodie, Kane and Marcus, 2011).The results of studies examining efficient market anomalies have discovered day-of-the-week effects, the weekend effect, the January effect, the month-of-the-year effect, the end-of-the-tax-year effect, and the Holiday effect.

Ramadan is fasting month is followed by Muslims around the world which is culminated with the celebration of Eid al-Fitr (Eid). Eid is also a major holiday commemorated by Indonesian with many festives and traditions, one of which is celebrated by homecoming moments of many Indonesians returning to their hometowns to celebrate Eid with families who are separated because they work in big cities like Jakarta and Surabaya. This homecoming event has become very popular among Indonesian Muslims because flocking back home not only as celebration but also as a manifestation of the awareness that humans will always return to the origin (Purwakananta and 
Abilawa, 2011). Besides, many Indonesian non-Muslims also use this moment for holiday vacation to stay in touch with relatives (Chotib, 2014).

This sudden migration activity that moves millions of people from big cities to their hometowns also an immense activity that drains the mind and energy of many Indonesian stakeholders (Purwakananta and Abilawa, 2011). Indonesian government estimates that in 2010, as many as 18.5 million people made homecoming, and in 2011, an estimated 26 million people performed the homecoming ritual. Purwakananta and Abilawa (2011) also estimated in 2017 the number of home comers at about 33 million people. This vast human movement is undoubtedly followed by a sizeable economic movement as well. The capitalization figure in 2010 is estimated to reach IDR 84.90 trillion and the remittances from Indonesian migrant workers around IDR 20 trillion. This figure accounts for $56 \%$ due to the costs of accommodation, tourism, and philanthropy (alms) and $44 \%$ due to the components of transportation, consumption during travel, and souvenirs. This figure is an extraordinary phenomenon for such a brief moment (Purwakananta and Abilawa, 2011).

Every time during Ramadan, the price of daily necessity goods always goes up and economy in general is always heated, as indicated by the increase in inflation rate (IR), consumer price index (CPI) and circulated hard cash or M1 money during Ramadan which has become a regular pattern every year. Statistics from Indonesia Statistic Bureau notes that IR as a tendency of rising prices for goods and services, and CPI as an index that calculates the average change in prices of a package of goods and services consumed by households in a period of a specific time, from 2012 to 2017 illustrate a consistent increase (Badan Pusat Statistik, 2017). Statistics from Bank Indonesia for the same period notes that hard cash M1 money which circulates during Ramadan, except for 2014 and 2015, is always increasing (Bank Indonesia, 2017).The agreeing comparison of month-on-month data between IR, CPI, and M1 during Ramadan and Eid al-Fitr is visible.

Table 1

Data of Month-on-Month Increase of IR, CPI, and MI during Ramadan and Eid

\begin{tabular}{ccccccc}
\hline Year & $\mathbf{2 0 1 2}$ & $\mathbf{2 0 1 3}$ & $\mathbf{2 0 1 4}$ & $\mathbf{2 0 1 5}$ & $\mathbf{2 0 1 6}$ & $\mathbf{2 0 1 7}$ \\
\hline Eid Date & 18-Aug-12 & 7-Aug-13 & 27-Jul-14 & 15-Jul-15 & 5-Jul-16 & 25-Jun-17 \\
IR $(\Delta \%)$ & 0.25 & 2.26 & 0.5 & 0.39 & 0.42 & 0.3 \\
CPI $(\Delta$ index $)$ & 1.27 & 4 & 1.04 & 1.12 & 1.67 & 0.89 \\
M1 $(\Delta$ in Billion IDR $)$ & 637 & 21,487 & $(27,200)$ & $(7,600)$ & 65,500 & 66,000 \\
\hline
\end{tabular}

\section{Source: (Badan Pusat Statistik, 2017).}

Given the religiosity of Indonesian Muslims and the vastness of religious celebrations, it is become essential to study whether people's moods affect the macroeconomic level. We notice that Ramadan (as preparation of Eid) gives a shocking effect on the Indonesian economy, one moment of economic activity that moves higher than usual, accelerating the economic turnover which should also be reflected in the movement or performance of Indonesia's stock market. Indonesia Stock Exchange (IDX) serves stock trading with 567 listed companies. IDX has a trading volume of about 1,925 billion shares in 2016 and 1,578 billion as of Semester 1, 2017. The market capitalization value was IDR 5,753 trillion in 2016 and IDR 5,829 trillion as of Semester 1, 2017. Besides, IDX has an LQ45 Index, which is the 45 most listed companies' performance and represents $70 \%$ of the value of trade transactions.

Therefore, the purpose of this study is to inspect potential anomalies in IDX, especially in its LQ45 index which should be more sensitive during Ramadan. We analyze weekly average returns in the Gregorian calendar adjusted to Hijri. The objective of this paper is to present an empirical analysis in order to challenge the existence of efficient market anomalies in LQ45. The main question concerning Ramadan's effect is whether there exists any significant difference between 
Saputro Ahmad, B. G. and Utami, W. (2019). "A study of Ramadan effect on the Indonesia Stock Exchange", Management and entrepreneurship: trends of development, 4 (10), pp. 67-78. Available at: https://doi.org/10.26661/2522-1566/2019-4/10-06

LQ45's return and abnormal return in Ramadan compared with the month before and after Ramadan in the period of 2012 to 2017. This paper is structured as follows: it starts with an overview of theoretical assumptions about EMH anomalies and empirical studies of the effects of Ramadan in the stock market in Muslim majority countries, offers data and methodology, and then presents the results of the research and provides conclusions.

\section{LITERATURE REVIEW}

Investment is a present commitment for a certain period to obtain compensation in the future. There are at least four investment theories that have been established and are with overgrowing support of researches conducted by many economists and investment experts, namely Efficient Market Hypothesis, Portfolio Theory (Markowitz Portfolio Theory), Capital Asset Pricing Model and Arbitrage Pricing Theory (Reilly and Brown, 2012). This paper observes the Efficient Market Hypothesis $(\mathrm{EMH})$, which states that a market is efficient when the price of security adjusts quickly to new information entering the market so that the current price reflects all information related to that security. EMH academic research has been conducted for 30 years, giving a real impact on the investment industry in providing insight into market behavior, but also providing the most controversial ones because pieces of evidence found are mixed or many are contradictory (Reilly and Brown, 2012). Some conclusions support the efficient market hypothesis, and others do not. The implications of these various conclusions need to be taken into account by investors in measuring the intrinsic value of investment assets, analyzing investment decisions, and forming investment portfolios.

Fama argues that there are three forms of EMH, namely the weak, semi-strong, and strong form (Fama, 1970). The weak form EMH assumes that the current price reflects all historical information related to the stock and the current rates of returns are not related to future profit levels. The strong-form EHM assumes that stock prices reflect all historical, public, and private information so that there are not any market actors that can benefit above the risk-adjusted rate of returns. The half-strong EHM assumes that the stock price reflects all historical and public information. One of research that examines half-strong EHM is event-studies, which examines how quickly stock prices adjust to specific significant economic events, or in other words, whether it is possible to invest in particular stocks after the announcement of important information (for instance; the release of financial statements, corporate actions, fundamental economic data, major news, etc.) and then gain significant profits. The half-strong EMH hypothesis should prove that if investors are unlikely to benefit significantly from the entry of public information into the market, researchers will calculate effects to the market where the return under study is compared to the market reference return in order to identify the abnormal rate of return.

Although EMH theory states that the asset's price value reveals all information, there are empirical studies find that anomalies occur due to fierce competition among market actors which make the price of securities go up too high (over-adjust) or down too low (under-adjust). So, the market needs time to absorb new information. Also, what makes it captivating for many people to always do research on EMH is because the studies provide evidence that supports (and does not support) EMH in the capital markets they study.

Anomalies found in EMH encourages new development to find answers or other explanations for those anomalies, then a new branch in financial economics emerged namely behavioral finance, which considers psychological characteristics that affect how humans act as the market actors. Behavioral finance believes that it can explain better some stock trading phenomena by using a model that recognizes that market actors do not always think thoroughly rationally, it explains the occurrence of "bias" in trading decisions. Behavioral finance assumes that the information structure and characteristics of investors, which forms a specific market community which influences the individual investor's decisions as a member of said community. They assume that emotions 
influence the human brain, and it often processes information using "shortcuts" or bias (Reilly and Brown, 2012).

One of the trading phenomena identified using behavioral finance model is noise traders. Studies found that when there was a change in market sentiment, traders tend to move together so that the stock price and volatility increased/decreased sharply. Noise traders tend to make decisions by following the herd without proper or adequate analysis, or they do but adjust them to match to the market sentiment. Their trading decisions tend to be impulsive and based on irrational sentiment, and typically follow trends and overreact to good and bad news. These behavioral finance phenomena may explain why there are some events/moments, which create an impact on market returns.

Research that examines the influence of Ramadan and Eid on the stock market has been widely carried out by previous researchers. Al-Hajieh, Redhead, and Rodgers(2011) found that during 1997 to 2007 research period there were Ramadan effects in Jordan's ASE (Amman Stock Exchange), BIST (Borsa Istanbul) Turkey, EGX (Egyptian Exchange) Egypt, IDX (Indonesia Stock Exchange), KUSE (Kuwait Stock Exchange), but there is no Ramadan effect in TAD (Tadawul) of Saudi Arabia and BASE (Bahrain Bourse).Weber and Nickol found that during 1980 to 2015 study period there were Ramadan effects on the ADX (Abu Dhabi Securities Exchange), BIST (Borsa Istanbul) Turkey, BVMT (Bourse des Valeurs Mobilières de Tunis) Tunisia, CSE (Chittagong Stock Exchange) Bangladesh, DFM (Dubai Financial Market), QE (Qatar Exchange), and TSE (Tehran Stock Exchange) (Weber \& Nickol, 2016). As for IDX (Indonesia Stock Exchange), Weber and Nickol did not found the Ramadan effect, but instead, they found that in Shaaban and Zulqida, IDX had a significant stock return (Weber \& Nickol, 2016). According to this research, IDX market players seem to have anticipated the economic heat of Ramadan and Eid by buying in Shaaban and taking profit action during Ramadan.

Alturki and Khan (2015) did not found the Ramadan effect in the Tadawul All Share Index (TASI) of the Saudi Stock Exchange (Tadawul) with data from 2000 till 2014. Iqbal, Kouser, and Azeem (2013) found the Ramadan-effect while researched the Karachi Stock Exchange 100 Index (KSE-100 Index) within the period 1992 till 2011. McGowan and Jakob (2010) conducted a study on the Shariah Index (SI) of the Kuala Lumpur Stock Exchange (KLSE) with sample period from 2000 till 2003 concluded that there was no economic stimulus prominent during Ramadan and Eid which may affect the SI index.

Besides those aforementioned Ramadan-effect researches, some other researchers have conducted studies on whether there are abnormal return patterns caused by any event of cultural tradition in other countries. Guo and Wang (2007) examined the Shanghai Stock Exchange during the sample period from 1992 till 2006, concluding that there was a March effect because there was a Chinese New Year when many companies gave their employees the benefits of increasing public consumption during the month, which in turn increased stock performance. Moosa examined the Kuwait Stock Exchange for the 1996-2005 period, revealing that there was significant seasonality in June, that the average return monthly stock that occurred in June was higher than in other months (Moosa, 2010). The main explanation put forward for this phenomenon is that the harsh climatic conditions in the summer of July and August significantly forced the proportion of the population of Kuwait (and hence stock traders) to leave the country for an overseas holiday. Before holiday the traders accumulate shares, causing upward pressure on stock prices and creating the June effect, besides which many issuers issue interim financial reports in June that affect traders' decisions.

Chan, Khanthavit, and Thomas (1996) conducted an intensive research in the Kuala Lumpur Stock Exchange (KLSE) Composite Index during 1972-1992, Stock Exchange of Singapore (SES) Strait Times Industrial Index during 1969-1992, and Stock Exchange of Thailand (SET) Index during 1975-1991, and found that the excess returns in Chinese New Year were positive and statistically significant. The practices of issuing cash bonuses during Chinese New Year may depress stock prices before the holiday with prices returning to normal afterwards. 
Saputro Ahmad, B. G. and Utami, W. (2019). "A study of Ramadan effect on the Indonesia Stock Exchange", Management and entrepreneurship: trends of development, 4 (10), pp. 67-78. Available at: https://doi.org/10.26661/2522-1566/2019-4/10-06

Perez provides an analysis of Apple Inc. (AAPL) stock return traded on the NYSE, using a sampling period from 2001 to 2010. During these ten years, statistically, the stock return in September was very significant. Apple was known to issue new products in September, which approached several holidays in the United States such as Thanksgiving, Halloween, Black Friday, and Christmas (Perez, 2011).There was a negative return in November and a positive return in May at the Damascus Securities Exchange (DSE) index during 2010 to 2015 due to the fiscal year-end for nearly all firms at DSE is December, and dividends payments which are usually in May. In Borsa Istanbul (BIST) within 2003 to 2012 period, investors seem to take long positions in the middle of the month and release their shares at the end of the month and the beginning of the following month.

Yatiwella and De Silva (2011) claimed that during 1985-2005 All Share The Colombo Stock Exchange Price Index (ASPI) had been significantly affected by domestic political crisis and the global economic crisis. Jakobsson and Henriksson (2010) suspected that during 2003-2010, Swedish tax policy affects the OMXS30 index of Swedish Nasdaq OMX's negative stock return in January. Simonsen and Lifjeld (2015) found classic positive January-effect in the Oslo Stock Exchange (OSE) during 1980-2014, Atsin (2015) did not found January effect 'in the Johannesburg Stock Exchange in South Africa during 2002-2013, but found significant weekend effect in small and mid-cap stock issuer.

\section{METHODOLOGY}

This study was conducted to determine whether Ramadan has effects on the IDX. The timeline observed in this study is from 2012 till 2017, and were solved LQ45 as the sample with an assumption that this index contains the most actively traded stocks on IDX, hence, the price movements tend to be more sensitive. The methodology used is event studies, designed to detect the Ramadan effects toward the LQ45 movement during Shaaban, Ramadan, and Shawwal. Unlike event studies that examine stock-splits, where one can measure the impact of stock-splits on stock returns by comparing returns on dates before and after stock split announcements; to measure the impact of Ramadan we use a slightly different method. Eid celebration, according to our observations, is a religious process that starts from the beginning of Ramadan, culminates on Eid's day and ends with the tradition of celebrating Eid, therefore, it is presumed that one will not be able to catch upon abrupt changes of the LQ45 movement. Thus, we come to a consideration that the effect of Ramadan (Eid) is more detectable if it is compared the LQ45 returns that occur in the months before the Eid season, to the ones on Eid, and to the ones on the after Eid.

We have designed three models to detect the Ramadan effect. First, stock returns that occur during Shaaban with Ramadan, which means returns that occur during the normal month are compared with those manifested during the month of the economic boom due to Eid's anticipation. Second, returns that occur during Ramadan are compared with Shawwal, where researcher will expose the difference between returns that occur during the economic boom with the months after. Finally, researcher compares the returns between Shaaban and Shawwal, in order to anticipate the findings of Weber and Nickol (2016) that IDX in Shaaban experienced a significant return. Figure 1 illustrates the framework of our methodology. Hypothesis provided as the framework in this particular study is null hypothesis $\left(\mathrm{H}_{0}\right)$ is that there is no significant difference in LQ45 returns and LQ45 abnormal returns during the month of Ramadan compared to the previous month (Shaaban), during the month of Ramadan compared to the following month (Shawwal), and during the Shaaban compared Shawwal throughout the period 2012 till 2017. 


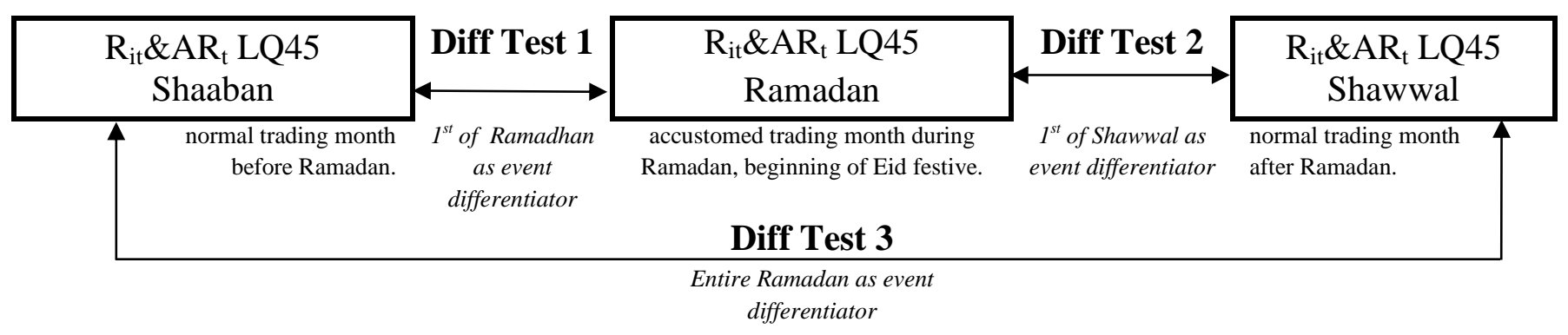

\section{Fig. 1. Framework Methodology}

We employ difference-test statistic to find out any significant LQ45 returns, which are contributed from Ramadan moments from 2012 till 2017. We calculate returns $\mathrm{R}_{\mathrm{it}}$ (returns of $\mathrm{i}$, in corresponding period time of $\mathrm{t}$ ) by the natural logarithm of averages of daily returns in week $w\left(\mathrm{P}_{\mathrm{w}}\right)$ compared to those in week $\mathrm{w}-1\left(\mathrm{P}_{\mathrm{w}-1}\right)$ as follows:

$$
R_{i t}=\ln \left(\frac{P_{w}}{P_{w-1}}\right)
$$

We calculate abnormal returns $\mathrm{AR}_{\mathrm{t}}$ by weighing LQ45 against Indonesia Stock Exchange Composite Index (IHSG) of the corresponding week as follows:

$$
A R_{t}=\left[\ln \left(\frac{L Q 45_{w}}{L Q 45_{w-1}}\right)-\ln \left(\frac{I H S G_{w}}{I H S G_{w-1}}\right)\right] \times 100
$$

If $\mathrm{R}_{\mathrm{it}}$ produces a negative number, we transform that into the smallest positive value, 0.0001 .

After that, we classify those $\mathrm{R}_{\mathrm{it}}$ and $\mathrm{AR}_{\mathrm{t}}$ according to their respected month Shaaban (SYB), Ramadan (RMD), and Shawwal (SYW). We believe those grouping can be adequate in detecting Ramadan influence in LQ45 returns, in which we will study the stock returns performance before, during, and after Ramadan. We believe that the Eid as the cut-off date for this study will be better observed its influence if we employ a broader examination window. Consumer tends to look forward to Eid-day about two weeks before, and corporations usually anticipate a month before.

We conduct normality testing to ensure that variables used in this research have normal distribution properties using the Kolmogorov-Smirnov test with a significance level of $0.05(p$ value $>0.05$ ) as an indicator that the research variables are normally distributed. Next, we work out hypothesis testing with three paired sample t-test statistical models as follows:

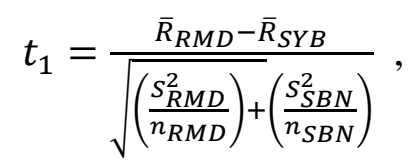
Ramadan;

where $\mathrm{t}_{1}$ tests the difference between returns before Ramadan (Shaaban) and during

$$
t_{2}=\frac{\bar{R}_{R M D}-\bar{R}_{S Y W}}{\sqrt{\left(\frac{s_{R M D}^{2}}{n_{R M D}}\right)+\left(\frac{s_{S Y W}^{2}}{n_{S Y W}}\right)}}
$$

where $t_{2}$ tests the difference between returns before Ramadan and after Ramadan (Shawwal); 
Saputro Ahmad, B. G. and Utami, W. (2019). "A study of Ramadan effect on the Indonesia Stock Exchange", Management and entrepreneurship: trends of development, 4 (10), pp. 67-78. Available at: https://doi.org/10.26661/2522-1566/2019-4/10-06

and

$$
t_{3}=\frac{\bar{R}_{S B N}-\bar{R}_{S Y W}}{\sqrt{\left(\frac{s_{S B N}^{2}}{n_{S B N}}\right)+\left(\frac{s_{S B N}^{2}}{n_{S Y W}}\right)}},
$$

where $t_{3}$ tests the difference between returns during Shawwal and Shawwal. As well the notation $\bar{R}_{R M D}, \bar{R}_{S B N}$, and $\bar{R}_{S Y W}$ are variable mean of return during Shaaban, Ramadan, and Shawwal; $S_{R M D}^{2}, S_{S B N}^{2}$, and $S_{S Y W}^{2}$ are variants of returns; and $n_{R M D}, n_{S B N}$, dan $n_{S Y W}$ are number of sample observations during the corresponding month.

Then we conduct this research's hypothesis testing, using F-test and t-test. Statistical F-test will show whether all variables included in the model have a mutual influence with level of significance at $\alpha=5 \%$. This means that if the p-value (sig) is less than 5\%, then all independent variable has a significant effect on the dependent variable. The t-test shows how strong the influence of independent variable individually in explaining the variation of the dependent variable with level of significance at $\alpha=5 \%$. This means that if the p-value (sig) is less than $5 \%$, then the independent variables have a significant effect on the dependent variable.

\section{RESULTS AND DISCUSSION}

The Liquid 45 (LQ45) index launched by IDX on February 24, 1997, consists of 45 stocks with the largest capitalization and highest trading volume. Sitting in the ranks of LQ45 is an honor for a company because it signifies the confidence of capital market and recognition of the company's excellent level of liquidity and market capitalization. LQ45 covers at least $70 \%$ of the stock market capitalization value and transaction value on the IDX.

During the period of our research from 2012 till 2017, there were 1,458 trading days with 238 to 246 days for each year, with total of 309 weeks, and throughout the observation period, the LQ45 index generally tends to experience a positive trend as Figure 2. We also add several markers to indicate month of Shaaban (checkered), Ramadan (flat-line), and Shawwal (diagonal-line). At first glance, except for 2015, all marker shows uptrend for Ramadan.

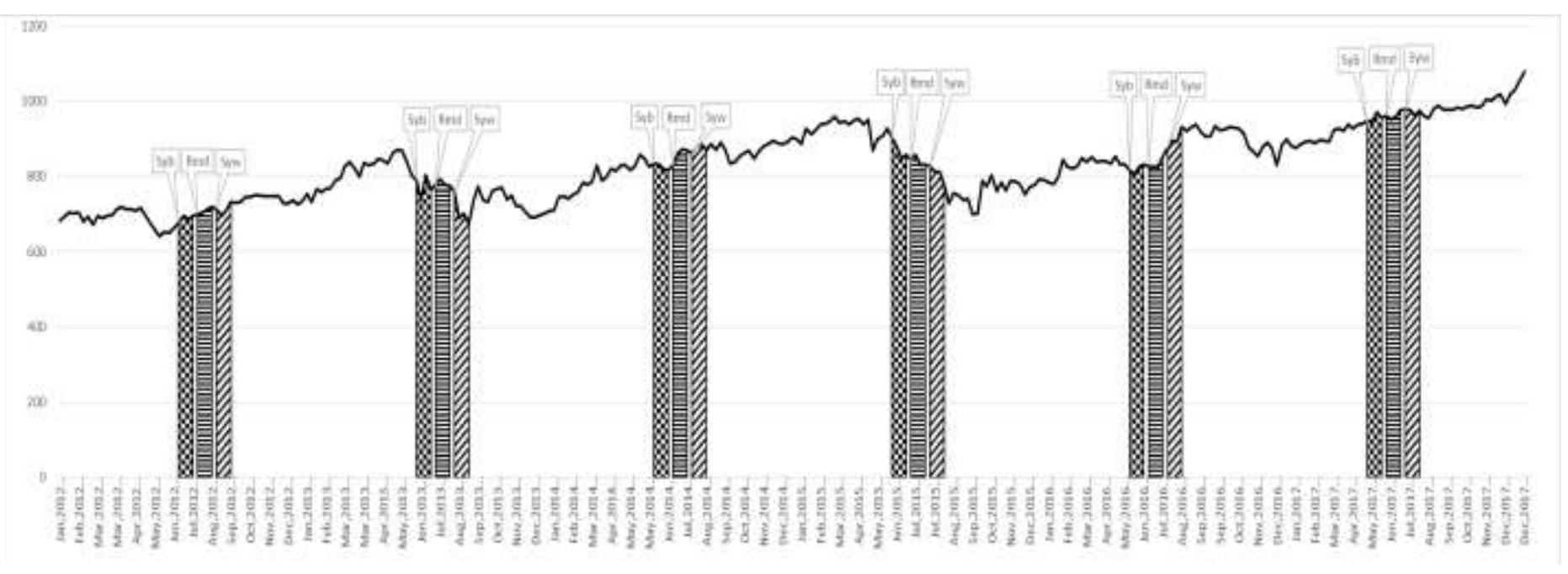

Figure 2. LQ45 Movement 2012-2017 
Table 2 presents summary statistics of weekly $R_{i t}$ and $A R_{t}$, which the sample mean, median, minimum, maximum, standard deviation, skewness, and kurtosis are reported. The mean returns are modest, while LQ45's abnormal returns actually underperform against IHSG; also the mean returns in Shaaban are negative, in Ramadan are positive, and in Shawwal are negative also alike as the abnormal returns.

Table 2

$R_{i t}$ and $A R_{t} L Q 452012$ to 2017 Descriptive Statistic

\begin{tabular}{|c|c|c|c|c|c|c|c|c|}
\hline & \multirow[t]{2}{*}{$\boldsymbol{R}_{i t}$} & \multirow[t]{2}{*}{$A R_{t}$} & \multicolumn{2}{|c|}{ Shaaban } & \multicolumn{2}{|c|}{ Ramadan } & \multicolumn{2}{|c|}{ Shawwal } \\
\hline & & & $\boldsymbol{R}_{i t}$ & $A R_{t}$ & $\boldsymbol{R}_{i t}$ & $\boldsymbol{A} \boldsymbol{R}_{t}$ & $\boldsymbol{R}_{i t}$ & $A R_{t}$ \\
\hline Mean & 526 & $\overline{01}$ & .000921 & .000085 & 001326 & .000261 & -0.000964 & 0 \\
\hline $\mathrm{Mec}$ & 38 & & 1641 & -0 & 04 & & 00808 & 88 \\
\hline Min & -0.096201 & -0.022769 & -0.015098 & -0.003 & -0.005518 & $-0 . C$ & -0.028432 & -0.002 \\
\hline $\mathrm{Ma}$ & 47 & 0 & 921 & 0 & 178 & & 9470 & 749 \\
\hline Std. & 0.024565 & & 06850 & 0.001 & 0.003584 & & 0.007451 & 0.001056 \\
\hline Ske & 0.03 & & 0020 & 0.6 & .450165 & & -2.236404 & -0.462948 \\
\hline Kurt & 3.205445 & 3.076340 & 50515 & 3.636489 & 0.154379 & 0.436782 & 7.536104 & -0.042491 \\
\hline $\mathrm{N}$ & 309 & 309 & 24 & 24 & 24 & 24 & 24 & 24 \\
\hline
\end{tabular}

Table 3 presents the Kolmogorov-Smirnov normality test which shows the result for $\mathrm{R}_{\mathrm{it}} \mathrm{sig}$ as 0,000 , therefore, $R_{i t}$ data sample is not normally distributed, consequently we will employ nonparametric Wilcoxon two related sample test for hypothesis testing instead of paired sample t-test statistical model. A different result was obtained for $\mathrm{AR}_{\mathrm{t}}$ with sig. 0.187 which means the data is normally distributed, and we will retain using paired sample t-test statistical model.

Table 3

One-Sample Kolmogorov-Smirnov Normality Test $R_{i t}$ and $A R_{t} L Q 45$

\begin{tabular}{|c|c|c|c|}
\hline & & $\mathbf{R}_{\text {it }}$ & $\mathbf{A R}_{\mathrm{t}}$ \\
\hline $\mathrm{N}$ & & 72 & 72 \\
\hline \multirow[t]{2}{*}{ Normal Parameters ${ }^{\mathrm{a}, \mathrm{b}}$} & Mean & -0.000006 & -0.000006 \\
\hline & Std. Dev. & 0.001264 & 0.001264 \\
\hline \multirow[t]{3}{*}{ Most Extreme Differences } & Absolute & 0.094 & 0.094 \\
\hline & Positive & 0.094 & 0.094 \\
\hline & Negative & -0.084 & -0.084 \\
\hline Test Statistic & & 0.157 & 0.094 \\
\hline Asymp. Sig. (2-tailed) & & $.000^{\mathrm{c}}$ & $.187^{\mathrm{c}}$ \\
\hline
\end{tabular}

a. Test distribution is Normal.

b. Calculated from data.

c. Lilliefors Significance Correction.

Decision-making for $\mathrm{R}_{\mathrm{it}}$ hypothesis based on the significance of Wilcoxon two related sample test in condition whether the p-value $>0.05$, then $\mathrm{H}_{0}$ is accepted and if $\mathrm{p}$-value $<0.05$, then $\mathrm{H}_{0}$ is rejected. Table 4 shows Pair 1 of $R_{i t}$ Shaaban compared to $R_{i t} R a m a d a n$ with $p$-value $=0.072$, Pair 2 of $R_{i t}$ Ramadan against $R_{i t}$ Shawwal with p-value $=0.241$, and Pair 3 of $R_{i t}$ Shaaban in contrast to $\mathrm{R}_{\text {it }}$ Syawal with $\mathrm{p}$-value $=0.732$. The $\mathrm{p}$-value of all three models produced a number greater than the threshold of a decision in rejecting null hypothesis. Therefore, there is no difference of $R_{i t}$ in Shaaban, Ramadan, and Shawwal, hence the null hypothesis retained. 
Saputro Ahmad, B. G. and Utami, W. (2019). "A study of Ramadan effect on the Indonesia Stock Exchange", Management and entrepreneurship: trends of development, 4 (10), pp. 67-78. Available at: https://doi.org/10.26661/2522-1566/2019-4/10-06

Table 4

Related-Samples Wilcoxon Signed Rank Test Result for $R_{i t} L Q 45$

\begin{tabular}{ccc}
\hline Models & $\begin{array}{c}\text { Null Hypothesis: the median } \\
\text { of differences between }\end{array}$ & Sig. \\
\hline Pair 1 & Sbn - Rmd & .072 \\
Pair 2 & Rmd - Syw & .241 \\
Pair 3 & Sbn - Syw & .732 \\
\hline
\end{tabular}

The paired sample t-test result significance also in condition whether the p-value $>0.05$, then $\mathrm{H}_{0}$ is accepted and if p-value $<0.05$, then $\mathrm{H}_{0}$ is rejected, and t-test decision making based on t-table criteria in condition whether $\mathrm{t}$-arithmetic $<\mathrm{t}$ table, then $\mathrm{H}_{0}$ accepted and if $\mathrm{t}$-arithmetic $>\mathrm{t}$-table, then $\mathrm{H}_{0}$ rejected, in this research $\mathrm{t}$ table for $\mathrm{df}=23$ and probability $=0.05$ is 1.71387 . Table 5 presents Pair 1 of $\mathrm{AR}_{\mathrm{t}}$ Shaaban against $\mathrm{AR}_{\mathrm{t}}$ Ramadan, mean returns that occurs between the two months is only $-0.03 \%$ with p-value $=0.359$, and $t$ value $=-0936$. Pair 2 of $A_{t}$ Ramadan compared to $\mathrm{AR}_{\mathrm{t}}$ Shawwal shows mean returns $0.04 \%$ with $\mathrm{p}$-value $=0.143$ and $\mathrm{t}$-value $=1.515$. Pair 3 of $\mathrm{AR}_{\mathrm{t}}$ Shaaban against $\mathrm{AR}_{\mathrm{t}}$ Shawwal shows mean returns $0.01 \%$ with $\mathrm{p}$-value $=0.778$ and $\mathrm{t}$-value $=0.286$. Also, in the test for $\mathrm{AR}_{\mathrm{t}}$, we found that both $\mathrm{p}$-value and $\mathrm{t}$-value in three models shows a number greater than the threshold of the decision in rejecting the null hypothesis. Therefore, similar as $\mathrm{R}_{\text {it }}$ that there is no difference of $\mathrm{AR}_{\mathrm{t}}$ in Shaaban, Ramadan, and Shawwal, hence the null hypothesis retained.

Table 5

Paired Sample t-test Result for $A R_{t} L Q 45$

\begin{tabular}{|c|c|c|c|c|c|c|c|c|c|}
\hline & \multirow{3}{*}{$\mathrm{AR}_{\mathrm{t}}$} & \multicolumn{5}{|c|}{ Paired Differences } & \multirow{3}{*}{$\mathrm{t}$} & \multirow{3}{*}{ df } & \multirow{3}{*}{$\begin{array}{l}\text { Sig. (2- } \\
\text { tailed) }\end{array}$} \\
\hline & & \multirow[t]{2}{*}{ Mean } & \multirow[t]{2}{*}{$\begin{array}{c}\text { Std. } \\
\text { Deviation }\end{array}$} & \multirow{2}{*}{$\begin{array}{l}\text { Std. } \\
\text { Error } \\
\text { Mean }\end{array}$} & \multicolumn{2}{|c|}{$\begin{array}{l}\text { 95\% Confidence } \\
\text { Interval of the } \\
\text { Difference }\end{array}$} & & & \\
\hline & & & & & Lower & Upper & & & \\
\hline Pair 1 & Sbn - Rmd & -0.000346 & 0.001809 & 0.000369 & -0.001110 & 0.000418 & -0.936 & 23 & 0.359 \\
\hline Pair 2 & Rmd - Syw & 0.000454 & 0.001467 & 0.000300 & -0.000166 & 0.001073 & 1.515 & 23 & 0.143 \\
\hline Pair 3 & Sbn - Syw & 0.000108 & 0.001853 & 0.000378 & -0.000674 & 0.000890 & 0.286 & 23 & 0.778 \\
\hline
\end{tabular}

Based on the results of the hypothesis testing, both $\mathrm{R}_{\mathrm{it}}$ and $\mathrm{AR}_{\mathrm{t}}$ from all three pair models do not meet the significance required so that the null hypothesis $\mathrm{H}_{0}$ accepted and the alternative hypothesis $\mathrm{H}_{1}$ rejected. The null hypothesis concluded that there was no significant difference in LQ45 returns and abnormal returns during the month of Ramadan compared to the earlier month (Shaaban) and later month (Shawwal) throughout 2012 to 2017 period. The similar condition is experienced by comparison of $R_{i t}$ and $A_{t}$ in Shaaban and Shawwal. This result concludes that Ramadan do not affect the LQ45 stocks price movement. This research suspects that the rising temperature of the economy during Ramadan as preparation for Eid was not reflected in its influence on stock market price movements in Indonesia. Thus, it was found that the quantitative phenomena observed such as the M1 money supply, the inflation rate, and the Consumer Price Index, as well as the qualitative phenomena observed such as the tradition of Eid al-Fitr celebrations and the Eid homecoming tradition were not detected affecting the performance of LQ45. Although we assuming that LQ45 stocks should be directly or indirectly benefited from the increased economic circulation that occurs during Ramadan, the phenomena observed did not attract the attention of market players.

Comparison of $\mathrm{R}_{\mathrm{it}}$ and $\mathrm{AR}_{\mathrm{t}}$ in Shaaban against Ramadan, wherein assuming that Shaaban applies regular trade, whereas Ramadan applies trade that increases due to anticipation of Eid did not occur in our study. Then comparison of $R_{i t}$ and $A R_{t}$ in Ramadan against Shawwal, where it is 
assumed that after Ramadan the market cools down and takes profit in Shawwal also did not happen in our study. Finally, comparison of $\mathrm{R}_{\mathrm{it}}$ and $\mathrm{AR}_{\mathrm{t}}$ in Shaaban and Shawwal as anticipation for Weber and Nickol (2016) finding that in Shaaban and Zulqida, IDX had a significant stock return, did not produce significant result as there is no difference between Shaaban against both Ramadan and Shawwal. These conditions found are the same as the result of McGowan and Jacob's (2010) research that did not find significant influence of Eid on the Sharia Index in the Kuala Lumpur Stock Exchange in 2000-2003; accordingly, there are similarities in the behavior of the capital market between Indonesia and Malaysia during Eid. The same condition also occurred in Saudi Arabia, Alturki and Khan (2015) conclude than there was no Ramadan effect in the Tadawul All Share Index (TASI) from 2000 till 2014.

The result of this study supports the half-strong EMH hypothesis which assumes that prices reflect all historical and public information, where the result proves that the future rate of return is impossible to predict using current public information. Besides, the results also unable to support the behavioral finance hypothesis, because there is no behavioral bias which may be influenced by Eid, experienced by market players in buying and selling decisions on IDX. Perhaps Eid has no influence on the information structure and the social-cultural collective character of market participants who jointly invest in IDX. This result means that during Ramadan, the market participants do not have a different behavioral pattern with the other months, or the market trading decision making employs variables other than Eid.

\section{CONCLUSION}

This research is an event study which examines whether prices adjust to specific significant economic events, which in this case is Ramadan. The aim of this study is to give more insight into the perennial question concerning the existence of EMH anomalies. We have chosen the analysis of potential calendar effect on the Indonesian stock market because there is an opportunity to observe the stock market movement by taking into account Ramadan. Also, we want to know whether behavioral finance supports this market, where religious festivals lead to a beautiful feeling among Muslims which will influence investment decision making. In the spirit of Eid which is an essential social-cultural event in Indonesia, we use t-test to examine Eid effect. Our analysis failed to provide empirical result that supports the presence of Ramadan influence in LQ45. Although it appears that Ramadan and Eid's festivals are accompanied by the rising of inflation rate, consumer price indices and the M1 money supply, it is not enough to attract the attention of market player.

These findings can be explained for some reasons. First, Ramadan has been anticipated every year and has already been considered as an annual routine activity and reflected in year-end financial statements. In other words, Ramadan and Eid festivals are expected to happen to provide reasonable profits to the business. Therefore, there are no abnormal returns expected by market players. Second, the Indonesian stock market coverage is still relatively small as many businesses that benefited from Ramadan festivals have not listed the company in stock market, yet. Also, while the stock market is a good barometer for the country economic performance, in Indonesia, the use of stock market index still requires larger room to grow to develop into useful parameter. Last, it is susceptive that companies listed in LQ45 have different return trends, perhaps in the same period, some have positive returns, and the others does not. Thus the combined stock price in LQ45 looked as if there were no significant price movements because there were trade-offs between profited stocks and suffered losses stocks. Hence it is proposed that future research be carried out at a more detailed level which takes samples of individual listed companies in LQ45.In short, the Ramadan and Eid festivals in Indonesia is not a significant event which can open the opportunity to get a substantial profit in Indonesia stock market, or in theory, can lead to an EMH calendar effect anomaly. 
Saputro Ahmad, B. G. and Utami, W. (2019). "A study of Ramadan effect on the Indonesia Stock Exchange", Management and entrepreneurship: trends of development, 4 (10), pp. 67-78. Available at: https://doi.org/10.26661/2522-1566/2019-4/10-06

However, we are aware that our results about Ramadan effect will be different from other research which use different statistical methods and observation windows. The effect of Eid on LQ45 might be more visible if the study uses a broader observation period, for example, more than ten years. Besides, Eid effect might be more detectable if the study looks at the magnitude of trade volumes changes that occur during the observation window. Future research can add other variables such as trading volume to detect differences in Shaaban, Ramadan, and Shawwal, using specific individual stock in LQ45 list as samples might better to detect whether Ramadan has impact to specific companies' business activities, and researchers can using broader windows like month-ofthe-year effect and other EMH anomalies such as size effect. Those alternatives are important questions that deserve further research. The result might be useful for investors, as we confirm Ramadan effect to LQ45 so that they are expected could use it as a reference in strategic, timing, and tactical asset allocation planning, and to review the performance of the optimal stocks portfolio.

\section{REFERENCES}

Al-Hajieh, H., Redhead, K. and Rodgers, T. (2011). "Investor sentiment and calendar anomaly effects: A case study of the impact of Ramadan on Islamic Middle Eastern markets", Research in International Business and Finance. Available at: https://doi.org/10.1016/j.ribaf.2011.03.004 (accessed 11 October 2019).

Alturki, F. M. and Khan, A. (2015). Seasonality in the Saudi stock market. Jadwa Investment, June. Available at: http://www.jadwa.com/en/download/seasonality-in-the-saudi-stockmarket/research-10-2-1-1 (accessed 13 October 2019).

Badan Pusat Statistik. (2017). Data dan Laporan Tahun 2012-2017. Available at: https://www.bps.go.id/Publikasi (accessed 12 October 2019), (in Indonesian).

Bank Indonesia. (2017). Data dan Laporan tahun 2012-2017. Available at: https://www.bi.go.id/id/publikasi/laporan-tahunan/bi/Default.aspx (accessed 12 October 2019).

Bodie, Z., Kane, A. and Marcus, A. (2011). Investments and portofolio management (Global Edi). New York: The McGraw-Hill Companies Inc.

Chan, M. W. L., Khanthavit, A. and Thomas, H. (1996). "Seasonality and cultural influences on four Asian stock markets", Asia Pacific Journal of Management. Available at: https://doi.org/10.1007/BF01733814 (accessed 13 October 2019).

Chotib, C. (2014). Mudik dan arus migrasi. Kompas.com Available at: https://nasional.kompas.com/read/2014/07/27/23175561/Mudik.dan.Arus.Migrasi?page=all (accessed 21 October 2019), (in Indonesian).

Fama, E. F. (1970). "Efficient Capital Markets: A Review of Theory and Empirical Work", The Journal of Finance. Available at: https://doi.org/10.2307/2325486 (accessed 20 October 2019).

Guo, S. and Wang, Z. (2007). Market Efficiency Anomalies: A Study of Seasonality Efffect on the Chinese Stock Exchange. Umea University.

Iqbal, M. S., Kouser, R. and Azeem, M. (2013). "Conventional and Islamic Anomalies in Karachi Stock Exchange”, Science International Journal Lahore, 25(4), pp. 999-1007.

Moosa, I. A. (2010). "Does Climatic Seasonality Produce Seasonality in Stock Returns? Evidence from an Emerging Stock Market", Journal of Applied Business and Economics, 11(2).

Perez, M. (2011). "Efficient Market Hypothesis and Apple Seasonality", Alhambra Investments. Available at: https://alhambrapartners.com/2011/12/11/efficient-market-hypothesis-andapple-seasonality/ (accessed 20 October 2019).

Purwakananta, A. and Abilawa, S. (2011). Ekonomi mudik potret potensi ekonomi mudik lebaran dan gagasan mudik berdayakan desa. Jakarta: Dompet Dhuafa Press. (in Indonesian).

Reilly, F. K. and Brown, K. C. (2012). Investment Analysis \& Portfolio Management. 10th ed. Mason, $\mathrm{OH}$ : South-Western Cengage Learning. 
Weber, C. S. and Nickol, P. (2016). "More on Calendar Effects on Islamic Stock Markets", Review of Middle East Economics and Finance. Available at: https://doi.org/10.1515/rmeef-20150039 (accessed 2 October 2019).

\section{ВИВЧЕННЯ ВПЛИВУ РАМАДАНУ НА ДІЯЛЬНІСТЬ ІНДОНЕЗІЙСЬКОЇ ФОНДОВОЇ БІРЖІ}

\author{
Bimo Galuh Saputro Ahmad \\ Університет Мерку-Буана \\ Джакарта, Індонезія
}

\author{
Wiwik Utami \\ Університет Мерку-Буана \\ Джакарта, Індонезія
}

Дане дослідження спрямоване на перевірку наявності істотних відхилень в прибутковості акцій в Шаабані (до Рамадану), Рамадані і Шаввалі (після Рамадану) на Індонезійській фондовій біржі (IDX). Дослідження проводилося на основі даних компаній, включених до індексів Liquid 45 (LQ45). Збір і аналіз даних засновані на значеннях щотижневої ціни закриття біржі в період з 2012 по 2017 роки. Методологія дослідження передбачає аналіз відповідних подій за умови помірного впливу ринку капіталу. У дослідженні використані такі аналітичні методи, як: критерії Уілкоксона і Парний t-критерій 3 рівнем достовірності 95\% або $\alpha=0,05$. Результати виявили відсутність значної статистичної різниці між прибутковістю LQ45 і прибутковістю в Шаабані, Рамадані і Шаввалі в досліджуваний період. В ході дослідження з'ясувалося, що Рамадан не має істотного впливу на діяльність Індонезійській фондової біржі.

Ключові слова: дослідження, Рамадан, дохід, відхилення, Liquid 45, Індонезійська фондова біржа

\section{ИЗУЧЕНИЕ ВЛИЯНИЯ РАМАДАНА НА ДЕЯТЕЛЬНОСТЬ ИНДОНЕЗИЙСКОЙ ФОНДОВОЙ БИРЖИ}

\author{
Bimo Galuh Saputro Ahmad \\ Университет Мерку-Буана \\ Джакарта, Индонезия
}

\author{
Wiwik Utami \\ Университет Мерку-Буана \\ Джакарта, Индонезия
}

Данное исследование направлено на проверку наличия существенных отклонений в доходности акций в Шаабане (до Рамадана), Рамадане и Шавале (после Рамадана) на Индонезийской фондовой бирже (IDX). Исследование проводилось на основе данных компаний, включенных в индексы Liquid 45 (LQ45). Сбор и анализ данных основаны на значениях еженедельной цены закрытия биржи в период с 2012 по 2017 год. Методология исследования предполагает анализ соответствующих событий при условии умеренного влияния рынка капитала. В исследовании использованы такие аналитические методы, как: критерии Уилкоксона и Парный t-критерий с уровнем достоверности 95\% или $\alpha=0,05$. Результаты выявили отсутствие значительной статистической разницы между доходностью LQ45 и доходностью в Шаабане, Рамадане и Шаввале в исследуемый период. В ходе исследования выяснилось, что Рамадан не оказывает существенного эффекта на деятельность Индонезийской фондовой биржи.

Ключевые слова: исследование, Рамадан, доход, отклонения, Liquid 45, Индонезийская фондовая биржа 